\title{
GROWTH AND EXPLOITATION STATUS (Channastriata Bloch, 1793) IN LUBUK LAMPAM FLOODPLAINS, SOUTH SUMATERA
}

\author{
Zulkarnaen Fahmi ${ }^{1}$, Syarifah Nurdawati ${ }^{2}$, Freddy Supriyadi ${ }^{2}$ \\ ${ }^{1}$ Researcher at Research Centre for Fisheries Management and Conservation, Jakarta \\ ${ }^{2}$ Researcher at Research Institute for Inland Fisheries, Palembang \\ Received March 12-2012; Received in revised form March 20-2013; Accepted April 08-2013 \\ Email: fahmi_prpt@indo.net.id
}

\begin{abstract}
Due to the economic importance of $C$. striatain Lubuk Lampam floodplains (Indonesia), this study is aimed to estimate the biological and population parameters required for proposing a future plan to sustain and manage this valuable fish resource. The growth, mortality and explotation ratio of Channa striata estimated by employing FiSATProgramme are reported. The parameters of Von Bertalanffy growth model of 1,529 sample fishes were estimated as $\mathrm{K}=0.36 /$ year, $\mathrm{L} "=72.98 \mathrm{~cm}$ and to $=-0.52$ year. The coefficients of total mortality $(Z)$, natural mortality $(M)$ and fishing mortality $(F)$ were $1.72,0.73$ and 0.99 year $^{-1}$ respectively. Relative yield per recruit analysis shows that the presentexploitation rate (E) was 0.58 . Yield per recruit can be maximized at the exploitation ratio of 0.5 and Lc/Linf values of 0.3 . The Yield per recruit and biomass per recruit models indicated that, the fisheries status of $C$. striatain Lubuk Lampam floodplains exceed the limit reference point (Fmax), thus stock of this species in Lubuk Lampam floodplains is indicated being driving down. Reduction in fishing effort and increase number of selective fishing gears are suggested to sustain the fishery of Channa striata in Lubuk Lampam floodplains.
\end{abstract}

KEYWORDS : Lubuk Lampam floodplains, growth, mortality, management, Biological reference points, Channastriata.

\section{INTRODUCTION}

Channa striata is commonly found in swamps, freshwater plains and also occurs in the lowland rivers, usually caught in bathymetric range of 1-2 m (Allington, 2002 in Makmur, 2004). The fish is widely distributed in the Southern Asia, Central Asia and along the South Eastern Asia from Thailand to Indonesia including Papua New Guinea (FAO, 2000 in Muflikhah, 2007).

There have been few studies published on $C$. striata in different areas of Indonesia, so it's biological aspect has been little described from several literatures. It is summarized that the maximum length of $C$. striatareportedly can reach about $100 \mathrm{~cm}$, while in several lake and dams in Indonesia asymptotic length of $C$. striata ranged 457 and $722 \mathrm{~mm}$ (Kartamihardja, 1994; 2000, Makmur, 2004). Spawning season of $C$. striata occurs in the rainy season with the peak period occurred from February to April. In the floodplains ecosystem, spawning occurs throughout the year, while the peak frequency of spawning occurs in the rainy season, it is seen from the observed diameter of the eggs contained at least 3 of the population size of the eggs in each month (Muflikhah et al., 2005; Makmur, 2003).

The species of Channa striata is commercially important freshwater fish and one of the major fish species in Lubuk Lampam floodplains. This area is a shallow basin located at about $60 \mathrm{~km}$ southeast of Palembang, South Sumatera. Due to high demand of this fish and habitat degradation, it is necessary to evaluate the population of this fish to ensure the proper management of this fishery.

Hence, the present study was design to provide a review preliminary assessment and management of the species of $C$. striata in Lubuk Lampam fishery. It is aimed to estimate the biological and population parameters required for proposing a future plan to sustain and manage this valuable fish resource.

\section{MATERIALS AND METHODS}

Random samples of C.striata were collected for nine months from the commercial catch in the landing site, in Lubuk Lampam floodplains during the period from April to November 2011 (Fig. 1). From each collected fish sample, total length and total weight were recorded to the nearest centimeters and gram, respectively. Length weight relationship was estimated for 1,529 fish of $C$. striataaccording to Le Cren (1951). The condition factor was calculated according to Hile (1936).

Growth parameter of $C$. striata was estimated using Von Bertalanffy growth model (1938) by fitting the FordWalford plot ( $L t$ vs $L(t+\Delta t)$, while $t_{0}$ was estimated by inverse Von Bertalanffy growth equation and $\mathrm{W}_{\text {inf }}$ was 
estimated by converting $\mathrm{L}_{\text {inf }}$ to the corresponding weight using length weight relationship.

$$
\begin{aligned}
& L(t+" t)=a+b^{*} L(t) \\
& \mathrm{K}=-\left(1 /{ }^{\prime \prime} \mathrm{t}\right)^{*} \ln \mathrm{b} \\
& \operatorname{Linf}=a /(-b) \text {. } \\
& \text { t0 }=1 / k{ }^{*} \log \text { eLinf }-\log e(\operatorname{Linf}-L t) \\
& \operatorname{Winf}=a^{\prime}{ }^{*} \operatorname{Linf}^{b^{\prime}}
\end{aligned}
$$

where, $L(t)=$ length of fish at time $(t)$ in $\mathrm{cm}$,

Linf = asymptotic length $(\mathrm{cm})$,

$\mathrm{K}=$ growth coefficient $\left(\right.$ year- $\left.^{-1}\right)$,

a $\quad=$ intercept $; \mathrm{b}=$ slope,

to = hypothetical age (in years) when length of fish at zero length,

Winf = asymptotic weight (gram)

$a^{\prime} \& b^{\prime}=$ length-growth coefficient.

Performance of length and weight were estimated according to Moreau et al. (1986). The maximum age was determined according to Pauly \& David (1981), and the massive maturity age was obtained using Richter-Evanov methods (1972).
The instantaneous total mortality coefficient $(Z)$ of C.striatain Lubuk Lampam floodplains was obtained by using length-converted catch curve method (Gayanilo et al., 1994). The natural mortality (M) was calculated using Pauly empirical formula (1980): Log $M=-0.0066-0.279 \log L_{\text {inf }}+0.6543 \log K+0.4634 \log$ $T$, where, $L_{\text {inf }} \& K$ are VBGF parameters and $T$ is the annual mean temperature $\left({ }^{\circ} \mathrm{C}\right)$. Instantaneous fishing mortality $(\mathrm{F})$ was calculated by subtracting the natural mortality coefficient (M) from the total mortality coefficient (Z).

The estimation of survival rates (S) was estimated by the equation $S=e^{-z}$ (Ricker, 1975). The exploitation ratio (E) was calculated for C.striata according to Baranov (1918) formula. Length at first capture and Length at recruitment (Lc\&Lr) were investigated from the equation of Beverton and Holt (1956 \& 1957). While Age at first capture and Age at recruitment (tc\&tr) were estimated by applying back calculation of growth equation of Von Bertalanffy.

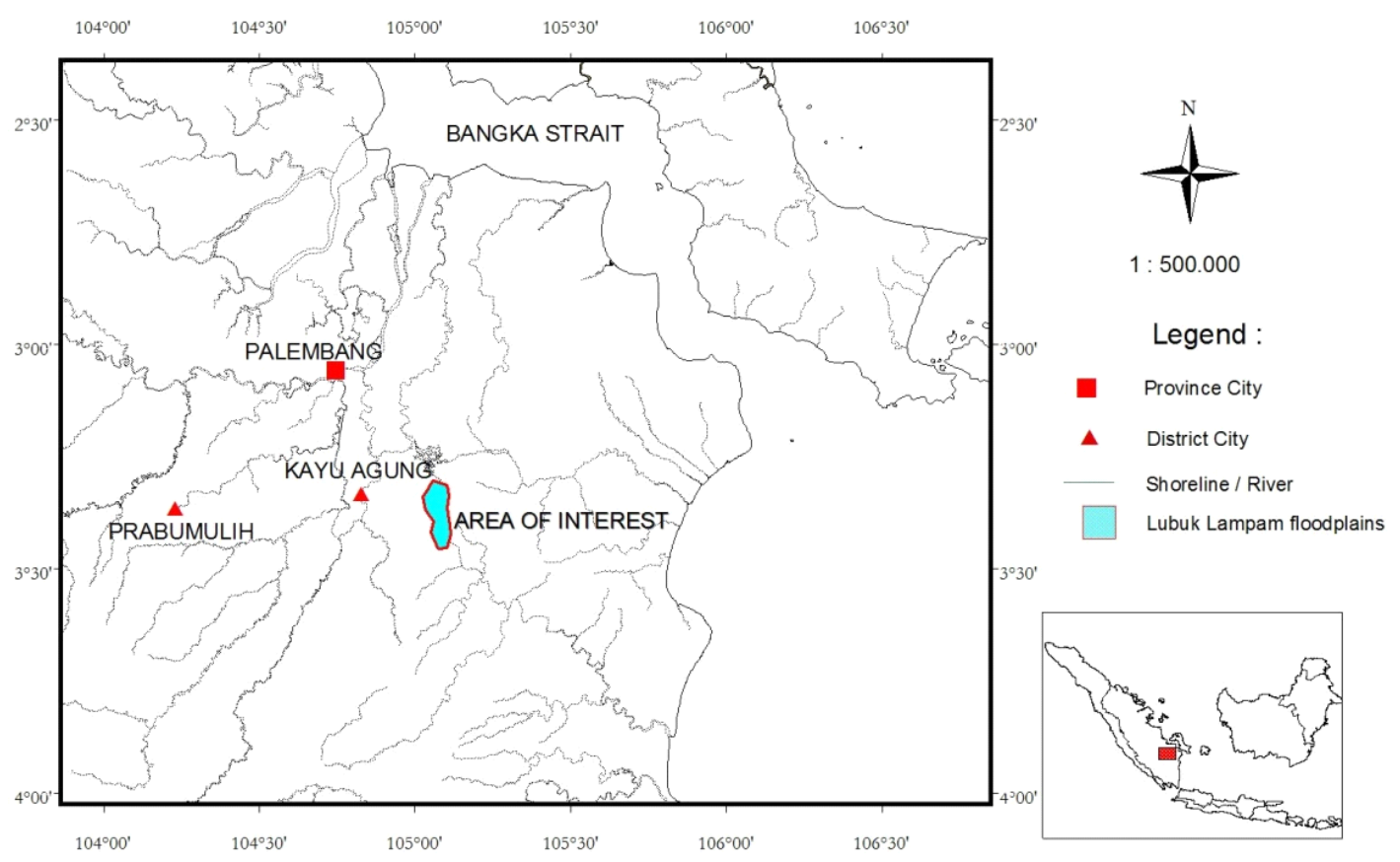

Figure 1. Lubuk Lampam floodplains location, South Sumatera.

The relative yield per recruit $\left(Y^{\prime} / R\right)$ and biomass per recruit (B'/R) were estimated by Beverton and Holt models (1957). The biological reference points values of fishing mortality such as $\mathrm{E}_{\max }$ and $\mathrm{E}_{0,1}$ were investigated together with various relationships between the yield per recruit, fishing mortality, age at first capture and natural mortality.

\section{RESULTS}

\section{Length-Weight Relationship and Condition Factor}

The examined sample of $C$. striata varied in length between 5.1 and $70.0 \mathrm{~cm}$ and from 7 to $2,997 \mathrm{gram}$ in weight. The condition factor (q) value of C.striata in Lubuk Lampam floodplains was found to be 0.9 , where length weight relationship equation was found to be: 
$W=0.0132 L^{2.8 / 85} \quad\left(R^{2}=0.973\right)$

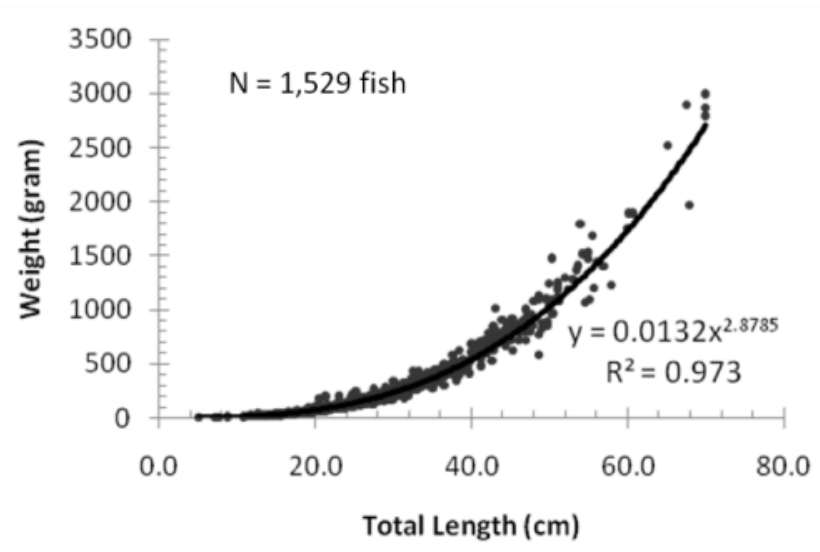

Figure 2. Length-Weight relationship of $C$. striata.

Monthly condition factor of Channa striata ranged from $0.5-2.2$ and monthly average ranged from 0.87 -0.90 . Condition factor of Channa striata fluctuated monthly affected by the difference of age, maturity, environment and food aviability in those area (Makmur, 2004). While growth pattern of $C$. striata showed isometric pattern in April and September, and allometric pattern in May-August and OctoberNovember (Table 1).

\section{Growth Performance and Maximum Age}

The growth parameters using Von Bertalanffy equation were estimated as $\mathrm{K}=0.36 /$ year, $L "=72.98$ $\mathrm{cm}$ and $\mathrm{t}_{0}=-0.52$ year. Values of W" obtained from length-weight relationship was estimated 3,049 gram. The growth performance values in length (ÔL) and in weight (ôW) of this species were 3.283 and 1.879 respectively. Growth performance values showed that C. striata growth rapidly in length than weight scales. According to the present data, it was found that maximum age (longevity) and age of massive maturity of $C$. striata in Lubuk Lampam floodplainsare 11.5 year and 2.60 year respectively. Monthly length frequency distribution of $C$. striata is showed in Figure 3.

Table 1. Condition factor of snakehead fish (Channa striata Bloch, 1793)

\begin{tabular}{ccccc}
\hline Month & Range & Average & L-W equation & $\mathbf{R}^{2}$ \\
\hline April & $0.6-1.5$ & 0.90 & $\mathrm{~W}=0.0079 \mathrm{~L}^{3.038}$ & 0.98 \\
May & $0.6-2.4$ & 0.88 & $\mathrm{~W}=0.0252 \mathrm{~L}^{2.662}$ & 0.96 \\
June & $0.6-1.3$ & 0.88 & $\mathrm{~W}=0.0054 \mathrm{~L}^{3.1449}$ & 0.99 \\
July & $0.6-2.1$ & 0.90 & $\mathrm{~W}=0.0128 \mathrm{~L}^{2.8921}$ & 0.96 \\
August & $0.5-1.5$ & 0.90 & $\mathrm{~W}=0.0166 \mathrm{~L}^{2.8121}$ & 0.97 \\
September & $0.7-1.6$ & 0.90 & $\mathrm{~W}=0.0088 \mathrm{~L}^{3.0042}$ & 0.98 \\
October & $0.6-2.2$ & 0.87 & $\mathrm{~W}=0.0205 \mathrm{~L}^{2.7359}$ & 0.97 \\
November & $0.7-1.2$ & 0.89 & $\mathrm{~W}=0.0143 \mathrm{~L}^{2.8527}$ & 0.98 \\
\hline
\end{tabular}

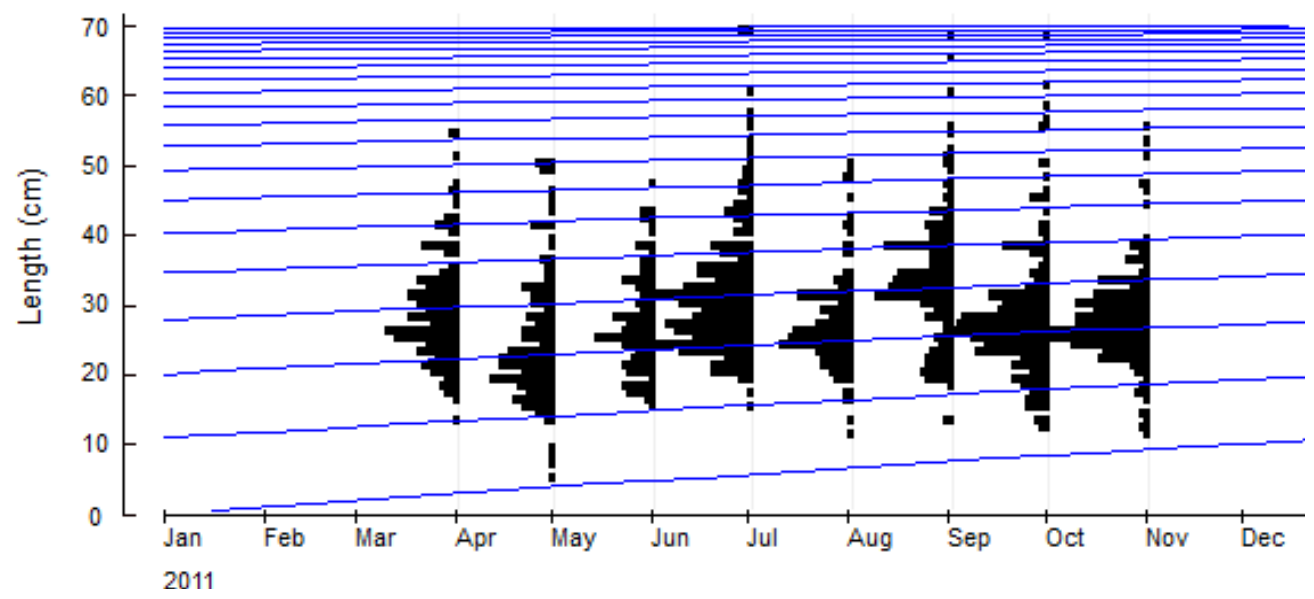

Figure 3. Length frequency distribution of $C$. striata 


\section{Mortality and Exploitation rate}

The length converted catch curve analysis for $C$. striata in Lubuk Lampam floodplains produced total mortality estimates of $Z=1.72 \pm 0.09$ (Figure 4). The natural mortality $\mathrm{M}=0.73$ is calculated using Pauly's empirical formula, with annual temperature about 29 ${ }^{\circ} \mathrm{C}$ (Pauly, 1980). The fishing mortality $(\mathrm{F})$ is therefore $0.99 /$ year. The survival rate value of $C$. striata in Lubuk Lampam floodplains was found to be 0.57 , while the exploitation ratio (E) was 0.58 . Length and age at first capture (Lcand tc) as obtained in the present study were found to be $21.44 \mathrm{~cm}$ and 0.70 year, while length at recruitment $(\mathrm{Lr})$ was $19.18 \mathrm{~cm}$ and the corresponding age at recruitment (tr) was 0.3 year.

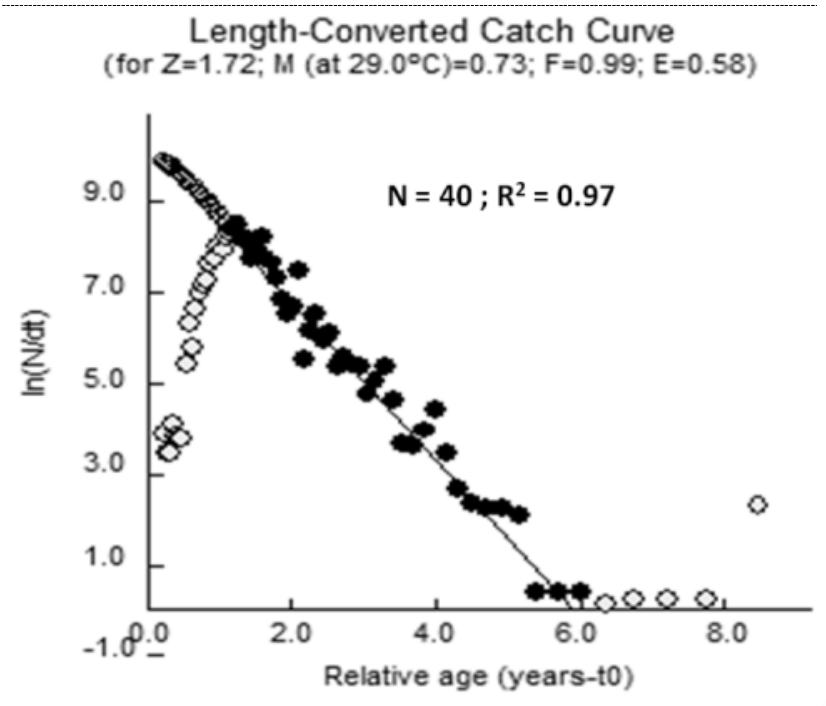

Figure 4. Length-Converted Catch Curve of C.striata in Lubuk Lampam floodplains.

\section{Recruitment Pattern}

Plot of the percentage recruitment of $C$. striata into the fishery in the portions of the floodplains showed continues recruitment from January to November with three pulses were recorded in March (14.2\%), April $(9.5 \%)$ and October $(14.7 \%)$ with average recruitment in one year was $8.3 \%$ (Figure 5 ).

\section{Relatif Yield Per Recruit (Y'/R) and Biomass Per Recruit (B'/R)}

Using knife edge selection of Beverton and Holt, the yield per recruit for $C$. striata in Lubuk Lampam floodplains with input parameter $\mathrm{M} / \mathrm{K}$ and $\mathrm{Lc} / \mathrm{Linf}$, and the optimum exploitation rates were calculated. The $E_{\max }, E_{0.1}$ and $E_{0.5}$ values for relative yield per recruit analysis were $0.52,0.41$ and 0.30 respectively (Figure
6). Relative yield per recruit analysis showed that the present exploitation rate (E) was 0.58 . Yield per recruit can be maximized at the exploitation ratio of 0.5 and $\mathrm{LC} / \mathrm{Linf}$ values of 0.3 . The exploitation rate $(\mathrm{E})$ in Lubuk Lampam floodplains was slightly higher than maximum acceptable limit and the position present exploitation value was on the right side of yield per recruit curve $\left(\mathrm{E}_{\text {present }}(0.58)>\mathrm{E}_{\text {max }}(0.52)\right)$.

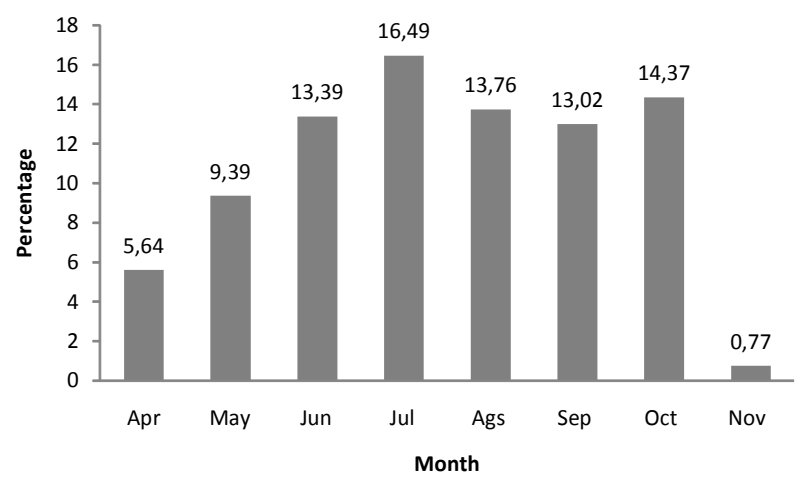

Figure 5. Recruitment pattern of $C$. striata in Lubuk Lampam floodplains.

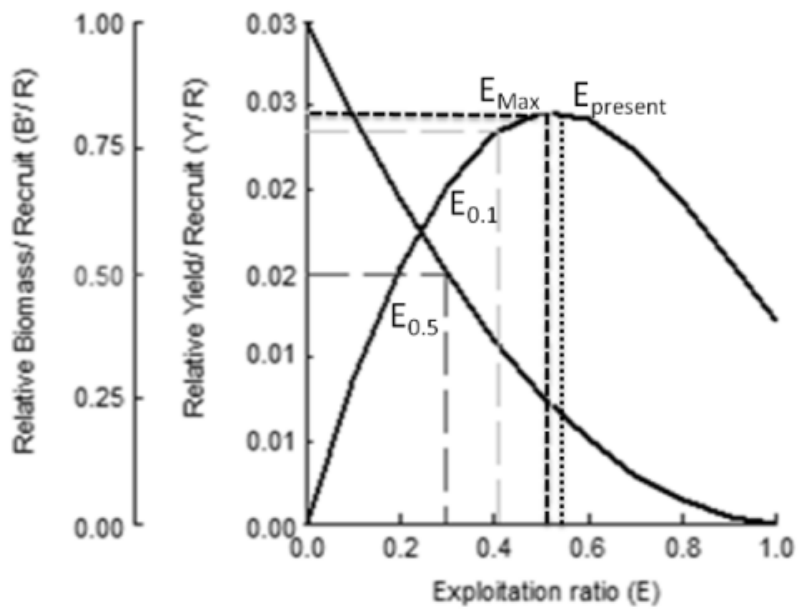

Figure 6. Relative Yield/Recruit and Relative Biomass/Recruit of C.striata in Lubuk Lampam floodplains.

\section{DISCUSSION}

In the present study, the value of the exponent "b" was found to be 2.8785 which indicated negative allometry. This value compared with previous study was higher than values of "b" of $C$. striata which was estimated by Kartamihardja (1994) in Kedungombo dams (2.743) and Makmur (2004) in Talang Fatima floodplains, South Sumatera, but still within the range of values in Banjaran River (2.77-3.123) (Table 2). 
Table 2. Von Bertalanffy growth parameters for $C$. striata in different places.

\begin{tabular}{|c|c|c|c|c|c|}
\hline Authors & $\mathrm{K}$ & Linf $(\mathbf{c m})$ & b & Location & \\
\hline $\begin{array}{l}\text { Kartamihardja et al., } 1994 \\
\text { Kartamihardja et al., } 2000\end{array}$ & $\begin{array}{l}0.40 \\
1.10\end{array}$ & $\begin{array}{l}66.93 \\
45.70\end{array}$ & 2.74 & $\begin{array}{l}\text { Kedungombo Dams, Central Java } \\
\text { Tondano Lake, North Sulawesi }\end{array}$ & \\
\hline Sinaga et al., 2000 & - & & $2.77-3.12$ & Banjaran River, Central Java & \\
\hline Makmur, 2004 & 1.36 & 72.20 & $1.23-1.14$ & $\begin{array}{l}\text { Talang Fatima flood plains, } \\
\text { Sumatera }\end{array}$ & South \\
\hline Kakkakeo et al., 2004 & 0.35 & 67.00 & & Ubolratana Reservoir, Thailand & \\
\hline Present study & 0.36 & 72.98 & 2.88 & $\begin{array}{l}\text { Lubuk Lampam floodplains, } \\
\text { Sumatera }\end{array}$ & South \\
\hline
\end{tabular}

In fisheries studies; the condition factor is an essential biological parameter needed to understand the suitability of the environment for good living of fish (Le Cren, 1951; Mahmoud et al., 2010). The condition factor $(\mathrm{k})$ was estimated 0.9 , compared with previous authors (Makmur, 2004) gave different values $(0.51$ 1.81). This controversy was explained to be due to the variations in the environmental conditions (Hernandez, 1986). The condition factor fluctuated monthly, affected by differences of age, gonad maturity and food suitability in their habitat (Makmur, 2004).

The growth performance index is considered to be a convenient and robust tool for the comparison of growth parameters from different data sets (Moreau et al., 1986 \& Pauly, 1980). The growth performance of $C$. striata in the present study, (ôL=3.283), which is lower than that observed by Kartamihardja, (1994) ( $\mathrm{O} \mathrm{L}=5.253$ ) in Kedungombo dams and Tondano Lake (2000) (ÔL=5.36) and Makmur (2004) in Talang Fatima floodplains (ÔL $=5.85$ ). Variations in the values of the parameter of growth performance might suggest variations in the growth rate (Moreau et al., 1986). The value of growth performance index in the present study compared with Makmur (2004) which has the same type of habitat and near geographic location has only half performance due to adaption flexibility on change of environmental condition.

Maximum age of $C$. striata in Lubuk Lampam floodplain scould live 11.50 years in the present study. The longevity of fish species might be affected by the environmental conditions under which a fish lives (Wootton, 1990; Mahmoud et al., 2010). C. striata is highly predacious species, ambush feeders on other fishes. In addition, their adaptability to living in turbid or clear waters, their apparent ability to tolerate extreme water temperature change were considered affected maximum age of this species.
The recruitment pattern established in this study revealed an all year around recruitment with three pulses in March, April, and October. This observation agreed to the assertion of Makmur et al., (2003) that C. striata in South Sumatera floodplains spawned along the year with length at recruitment (Lr) 15.4$18.0 \mathrm{~cm}$ while in the present study value of $\mathrm{Lr}$ was $19.18 \mathrm{~cm}$ respectively.

Species C. striata in the present study estimated, that exploitation rate $E=0.58$ showed that fishing mortality was higher than natural mortality. The implication is that $C$. striata died more due to human exploitation than natural death (e.g disease, predation etc). For an optimally exploited stock, natural and fishing mortalities should be equal or $E=0.5$ (Gulland, 1971; Abowei et al., 2010). The maximum exploitation rate (Emax), which gives maximum relative yield-perrecruit, is estimated at 0.52 and slightly differs from the exploitation rate $(0.58)$ estimated in this study. This further indicated that the stock of $C$. striata is driving the stock down into overfished condition.

\section{CONCLUSIONS}

Channa striata in Lubuk Lampam floodplains shows a negative allometric growth. Although this species recruits along the year, the stock has slightly reached an overfished phase $\left(\mathrm{E}_{\text {present }}>\mathrm{E}_{\text {max }}\right)$. This was due to the fishing mortality for $C$. striata is higher than the natural mortality. Therefore, it is necessary to reduce fishing effort tand applied selective fishing gears to maintain fish stocks sustainably.

\section{ACKNOLEDGEMENTS}

This study is based on the data collected from the project of implication climate change on fish resources in Musi River funded by Research Institute for Inland Fisheries, Palembang. We thank to the Director of RIIF for the funding support. 


\section{REFERENCES}

Abowei, J.F.N., George, A.D.I. \& Davies, O.A. 2010. Mortality, Exploitation rate and Recruitment pattern of Callinectesamnicola (De Rochebrune, 1883) from Okpoka Creek, Niger Delta, Nigeria. Asian Journal of Agricultural Sciences. ISSN: 2041-3890. 2(1): $27-34$

Baranov, F.I. 1918. On the question of the biological basis of fisheries. Nauchniisledouates kiilnntiologicheskiinstitatelsvesti (1): 18 - 128.

Beverton, R.J.H. \& Holt, S.J.H. 1956. A review of methods for estimating mortality rates in exploited fish populations, with special reference to sources of bias in catch sampling. Rapp. P. - V. - Re - un. CIEM, 140: 67 - 83.

Beverton, R.J.H. \& Holt, S.J.H. 1957. On the dynamics of exploited fish population. Fishery Investigations, Series II (London), 19: 1- 533.

Gayanilo, F.C.,Jr., Sparre, P. \& Paully, D. 1994. The FAO-ICLARM stock assessment tools (FiSAT) user guide. FAO Computerized Information Series (Fisheries). FAO, Rome. No. 7. 186 p.

Hernandez, A. H. V. 1986. Study on the age and growth of bogue (Boopsboops) from the central Adriatic Sea. Cybium (13): 281 - 288.

Hile, R. 1936. Age and growth of the Cisco Leucichthyartedi (Le Sueur) in the lakes of the North Eastern highlands, Wisconsim. Bull. U. S. Bur. Fiah., 19: 211 -317.

Kakkaeo, M., Chittapalapong,T. \& Villanueva, M.C. 2004. Food habits, Daily ratio and Relative Food Consumption in Some Fish Populations in Ubolratana Reservoir, Thailand. Asian fisheries science 17: 249-259.

Kartamihardja, E.S. 1994. Biologi reproduksi populasi ikan gabus Channa striata di Waduk Kedungombo. Buletin Penelitian Perikanan Darat. 12(2): 113-119.

Kartamihardja, E.S. 2000. Laju pertumbuhan, mortalitas, rekruitmen, eksploitasi stok ikan dominan, dan total hasil tangkapan ikan di Danau Tondano Sulawesi Utara. Jurnal Penelitian Perikanan Indonesia. 6 (2): 1-9.

Le Cren, E.D. 1951. The length weight relationship and seasonal cycle in gonad weight and Condition in the perch (Percafluviaittlis). J. Anim. Ecol. 20: $201-219$.

Mahmoud, H.H., Osman, A.M., Ezzat, A.A., Saleh, A.M. 2010. Biological status and management of Diplodus vulgaris (Geoffroy Saint-Hilaire, 1817) in Abu Qir Bay, Egypt. Egyptian Journal of Aquatic Research. ISSN: 1687-4285. 36 (1), 115-122.

Makmur, S., Rahardjo, M.F., \& Sutrisno, S. 2003. Biologi Reproduksi Ikan Gabus (Channa striata Bloch) di Daerah Banjiran Sungai Musi Sumatera Selatan. Jurnal Iktiologi Indonesia. 3 (2) : 57-62.

Makmur, S. 2004. Pertumbuhan Ikan Gabus (Channa striata Bloch) di daerah banjiran Talang Fatima DAS Sumatera Selatan. JPPI Edisi Sumber Daya dan Penangkapan.10 (6) : 1-6.

Moreau, J., Bambino, G. \& Pauly, D. 1986, Indices of overall growth performance of Tilapia (Cichlidae) Populations. J. Mar. Boil. Ass U.K. In J.L Maclean, L.B Dizon and L. V. Hosillos (eds) The First Asian Fisheries Forun. Asian Fisheries Society, Manilla, Philippines. 3 (2): 201-206.

Muflikhah, N., Nurdawati, S. \& Fatah, K. 2005. Pertumbuhan ikan gabus (Channastriata) dengan padat tebar berbeda. Prosiding Seminar Nasional dan Kongres Biologi XIII. Yogyakarta. Perhimpunan Biologi Indonesia Cabang Yogyakarta Bekerja Sama dengan Fakultas Biologi Universitas Gadjah Mada. Yogyakarta. p. 551-555.

Muflikhah, N. 2007. Domestikasi Ikan Gabus (Channastriata). Bawal. 1 (5): 169-175.

Pauly, D. \& David, N. 1981. Elefan I. basic program for the objective extraction of growth parameters from length frequency data. Neerefforfchung, 28 (4): 205 - 211.

Radwan A. 1996, Hydrographic structure and heat budget of Abu Qir Bay. M.Sc. Thesis, Facul. Sci. Alex. Univ. $101 \mathrm{p}$.

Pauly, D. 1984. Some simple methods for the assessment of tropical fish stock. FAO. 52 p.

Ricker, W.E. 1975. Computation of biological statistics of fish populations. Bull. Fish.Res. Broad of Canada. (191): 2-6.

Sinaga, T. P., Rahardjo, M.F. \& Syafei, D.S. 2000. Bioekologi ikan gabus (Channastriata) pada aliran Sungai Banjaran Purwokerto. Prosiding Seminar 
Growth And Exploitation Station....... Lubuk Lampam Floodplains, South Sumatera (Fahmi, Z., et al.)

Nasional Keanekaragaman Hayatilkan. Pusat Studi Ilmu Hayati IPB dan Pusat Penelitian dan Pengembangan Perikanan Biologi LIPI, Bogor :p. 133-140.

Von Bertalanffy, L. 1938. A quantitative theory of organic growth. Hum. Biol., 10 (2):181 - 213.
Walford, L.A. 1946. A new graphic method of describing the growth of animals. Biol. Bull. Mar. Biol., 90 (2): $141-147$.

Wootton, R.J.: 1990. Ecology of teleost fishes. Chapman and Hall Ltd. U.S .A. 404p. 